\title{
PENGENALAN TEKNOLOGI BERBASIS WEB UNTUK MENDUKUNG USAHA PENJUALAN TANAH KAVLINGAN
}

\author{
Ahmad Sanmorino1) \\ 1)Program Studi Sistem Informasi Universitas Indo Global Mandiri \\ Jl. Jend Sudirman No.629 Km.4 Palembang 30113 \\ Email : sanmorino@uigm.ac.id1)
}

\begin{abstract}
ABSTRAK
Perkembangan dibidang teknologi dan ilmu pengetahuan membuat organisasi harus semakin peka dalam peningkatan kualitas sumber daya yang dimilikinya. Oleh karena itu untuk menyikapi fenomena tersebut perlu adanya tindak lanjut dari organisasi sebagai upaya agar kemampuan yang dimiliki karyawannya tidak statis akan tetapi berkembang secara dinamis. Salah satunya yaitu dengan adanya Pengenalan teknologi berbasis web untuk mendukung usaha penjualan tanah kavlingan di Kelurahan Muara Dua Kota Prabumulih. Kegiatan pelatihan ini menjelaskan tentang manfaat penggunaan teknologi berbasis Web untuk mendukung usaha penjualan tanah kavlingan. Tujuan kegiatan ini adalah memberikan pemahaman kepada para pekerja pada usaha penjualan tanah kavlingan di Kelurahan Muara Dua Kota Prabumulih tentang penggunaan teknologi berbasis web untuk meningkatkan penjualan tanah kavlingan di Kelurahan Muara Dua Kota Prabumulih.
\end{abstract}

Kata kunci : Teknologi, web, penjualan, tanah kavlingan

\section{PENDAHULUAN}

Seiring dengan perkembangan teknologi informasi dan perubahan-perubahan dunia yang semakin hari semakin kompleks, menuntut seseorang untuk selalu menyegarkan kembali kemampuan yang dimilikinya sesuai dengan kapasitas perubahan tersebut. Membangun karir merupakan salah satu tugas perkembangan yang akan dilalui dalam kehidupan individu yang harus terus meningkatkan kemampuannya agar dapat membangun karir ataupun jabatan yang dimilikinya. Sebaliknya, suatu organisasi juga akan semakin maju dan berkembang apabila sumber daya yang dimiliki oleh karyawannya baik dan berkualitas. Pemanfaatan teknologi informasi juga dirasakan untuk berbagai aspek kehidupan seperti ekonomi, teknik, mekanik, ilmu kesehatan atau kedokteran, ilmu komputer [1]-[2], pertanian dan perkebunan, serta keamanan system [3].

Perkembangan dibidang teknologi dan ilmu pengetahuan membuat organisasi harus semakin peka dalam peningkatan kualitas sumber daya yang dimilikinya. Tak jarang pula sumber daya manusia atau karyawan yang menduduki jabatan tertentu dalam organisasi mempunyai kemampuan yang sesuai dengan persyaratan yang diperlukan. Oleh karena itu untuk menyikapi fenomena tersebut perlu adanya tindak lanjut dari organisasi sebagai upaya agar kemampuan yang dimiliki karyawannya tidak statis akan tetapi berkembang secara dinamis. Salah satunya yaitu dengan adanya Pelatihan Pengenalan teknologi berbasis web untuk mendukung usaha penjualan tanah kavlingan pada di Kelurahan Muara Dua Kota Prabumulih. Selain itu juga ternyata masih ada pekerja yang kurang menguasai atau memiliki sedikit pengetahuan tentang kompetensi pekerjaan yang ditekuninya. Kegiatan pelatihannya sendiri telah dilaksanakan pada tanggal 17 Juni 2018. Dengan kegiatan ini diharapkan para pekerja di usaha penjualan tanah kavlingan di Kelurahan Muara Dua Kota Prabumulih dapat meningkatkan kemampuan pekerja sehingga semakin meningkatkan penjualan tanah.

\subsection{Target Dan Luaran}

\section{a. Target}

Target kegiatan ini adalah pemilik dan para pekerja pada usaha penjualan tanah kavlingan di Kelurahan Muara Dua Kota Prabumulih supaya dapat memahami manfaat teknologi berbasis web untuk mendukung usaha penjualan tanah kavlingan supaya dapat meningkatkan produktivitas dalam bekerja. 


\section{b. Luaran}

Adapun Luaran dari pelatihan pemanfaatan teknologi berbasis web untuk mendukung usaha penjualan tanah kavlingan, adalah sebagai berikut:

1. Meningkatkan produktivitas dalam menyelesaiakan pekerjaan.

2. Menambah pengetahuan pekerja tentang pentingnya pemanfaatan teknologi berbasis web untuk mendukung usaha penjualan tanah kavlingan.

\section{METODE PELAKSANAAN PENGABDIAN}

Pelaksanaan pengabdian masyarakat dilakukan dengan memberikan penjelasan dan pengenalan pemanfaatan teknologi informasi berupa aplikasi pengolahan data berbasis web pada usaha penjualan tanah kavlingan di Kelurahan Muara Dua Kota Prabumulih. Adapun rincian kegiatan yang meliputi waktu, jadwal dan peserta diuraikan sebagai berikut:

\subsection{Tempat dan Waktu Kegiatan}

Kegiatan dilaksanakan di Usaha Muara Dua Property, Jl. Jend Sudirman No.01 RT/RW 01/07 Kel. Muara Dua, Kota Prabumulih 31114. Pelaksanaan kegiatan dilakukan pada tanggal 17 Juni 2018.

Sebelum kegiatan pengabdian pada masyarakat dilakukan perlu adanya persiapan yang harus dilakukan terlebih dahulu yaitu:

1. Merencanakan kegiatan pengabdian masyarakat dan memastikan dapat diterima oleh pemilik Usaha Penjualan Tanah Kavlingan di Kelurahan Muara Dua Kota Prabumulih.

2. Menetapkan hari, tanggal kegiatan, tempat serta peralatan yang perlu dipersiapkan untuk pelaksanaan kegiatan pelatihan tersebut.

3. Mengajukan rencana kegiatan pengabdian masyarakat kepada Ketua LP2MK Universitas Indo Global Mandiri.

4. Mempersiapkan bahan/materi pelatihan yang akan dibagikan kepada pemilik dan para pekerja sebagai peserta pelatihan.

5. Mempersiapkan feedback dan evaluasi pelatihan dalam bentuk kuesioner yang akan dibagikan kepada pemilik dan para pekerja sebagai peserta pelatihan.

6. Setelah persiapan selesai, ditetapkan waktu kegiatan pada tanggal 17 Juni 2018 di Usaha Penjualan Tanah Kavlingan di Kelurahan Muara Dua Kota Prabumulih.

\subsection{Peserta Kegiatan}

Diikuti oleh pemilik dan para pekerja pada Usaha Penjualan Tanah Kavlingan di Kelurahan Muara Dua Kota Prabumulih.

\subsection{Jadwal Kegiatan}

Adapun jadwal kegiatan pengabdian masyarakat "Pengenalan Teknologi Informasi Pada Usaha Penjualan Tanah Kavlingan" adalah sebagai berikut:

Tabel 1. Jadwal Kegiatan

\begin{tabular}{|c|c|c|}
\hline WAKTU & MATERI & FASILITATOR \\
\hline \multicolumn{3}{|c|}{ Minggu, 17 Juni 2018 } \\
\hline $08.00-09.00$ & $\begin{array}{c}\text { Tatap muka tim PPM UIGM } \\
\text { dengan pemilik dan pekerja } \\
\text { usaha penjualan tanah } \\
\text { kavlingan }\end{array}$ & $\begin{array}{c}\text { Pemilik Usaha Penjualan Tanah } \\
\text { Kavlingan dan Tim Pengabdian } \\
\text { Masyarakat UIGM }\end{array}$ \\
\hline \multicolumn{2}{|c|}{ Minggu, 17 Juni 2018 } \\
\hline $09: 00-11: 00$ & $\begin{array}{c}\text { Tujuan dan manfaat } \\
\text { penggunaan teknologi } \\
\text { berbasis web untuk }\end{array}$ & Tim Pengabdian Masyarakat UIGM \\
\hline
\end{tabular}




\begin{tabular}{|c|c|l|}
\hline & $\begin{array}{c}\text { mendukung usaha penjualan } \\
\text { tanah kavlingan }\end{array}$ & Minggu, 17 Juni 2018 \\
\hline \multicolumn{3}{|c|}{} \\
\hline \multicolumn{2}{|c|}{ Menutupan } & Tim Pengabdian Masyarakat UIGM \\
\hline 11:00 - 12:00 & Pen
\end{tabular}

\section{HASIL DAN PEMBAHASAN}

Pemahaman pemanfaatan teknologi berbasis web untuk mendukung usaha penjualan tanah kavlingan, dapat meningkatkan produktivitas kinerja dengan memanfaatkan teknologi Informasi. Kemampuan penggunaan teknologi berbasis web untuk mendukung usaha penjualan tanah kavlingan dan pemeliharaannya untuk berbagai keperluan dapat dipergunakan oleh para pekerja untuk keperluan diluar dari kepentingan usaha. Dengan pengetahuan dasar penggunaan komputer yang baik, diharapkan para pekerja Usaha Penjualan Tanah Kavlingan di Kelurahan Muara Dua Kota Prabumulih khususnya, dapat mengembangkan ilmu yang didapat selama pelatihan. Dapat membantu Usaha Penjualan Tanah Kavlingan di Kelurahan Muara Dua Kota Prabumulih semakin maju dan berkembang dikarenakan meningkatnya keahlian dan keterampilan yang dimiliki oleh para pekerja.
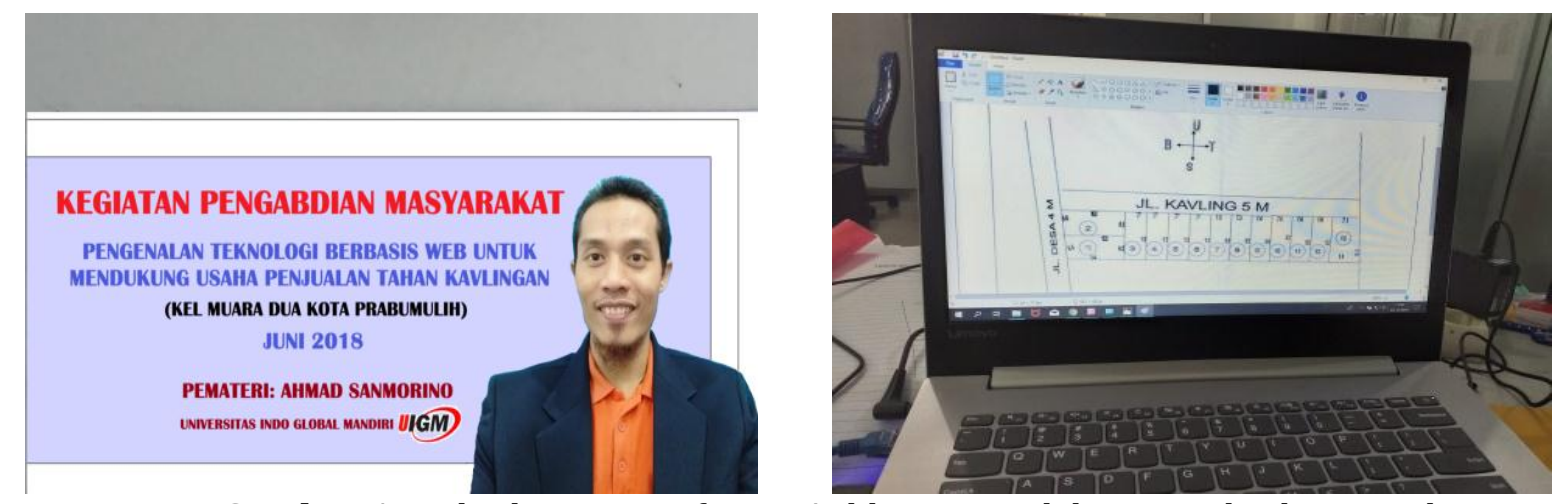

Gambar 1. Pelatihan Pemanfaatan Aplikasi Pengolahan Data berbasis Web pada Usaha Air Bersih

Adapun contoh katalog dari aplikasi penjualan tanah kavlingan yang kami gunakan didalam pelatihan adalah sebagai berikut:

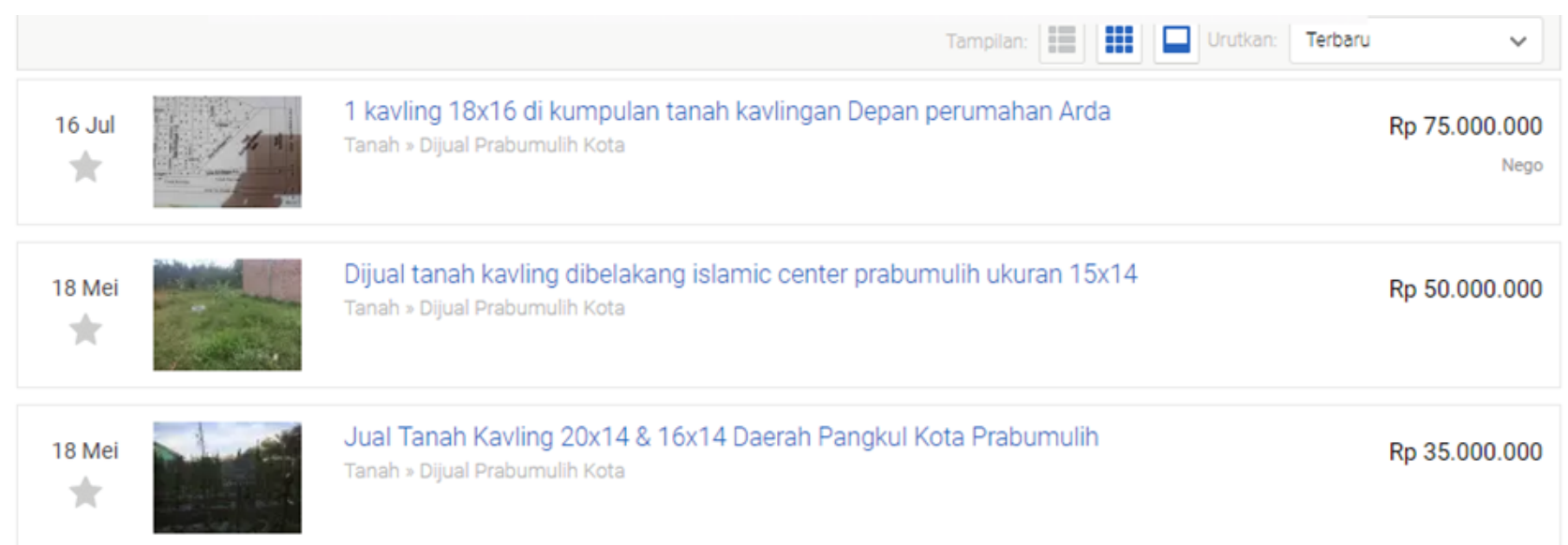

Gambar 2. Contoh Katalog Penjualan Aplikasi Tanah Kavlingan

Adapun spesifikasi perangkat yang dibutuhkan untuk dapat mengimplementasikan perangkat teknologi informasi berupa aplikasi berbasis web adalah sebagai berikut: 
Tabel 2. Spesifikasi Perangkat

\begin{tabular}{|l|l|}
\hline Nama Perangkat & Kuantitas \\
\hline Komputer Personal (PC) & 1 \\
\hline Canon Pixma E400 & 1 \\
\hline Windows OS & 1 \\
\hline Modem 3G & 1 \\
\hline $\begin{array}{l}\text { Paket XAMPP (Apache, } \\
\text { PHP, MySQL) }\end{array}$ & 1 \\
\hline
\end{tabular}

\section{KESIMPULAN}

Adapun kesimpulan dari kegiatan pengabdian masyarakat di usaha penjualan tanah kavlingan di Kel Muara Dua, Kota Prabumulih yang telah dilakukan adalah sebagai berikut:

1. Kegiatan terlaksana sesuai dengan tujuan dan rencana.

2. Kegiatan ini mendapat sambutan yang baik dari para pekerja Usaha Penjualan Tanah Kavlingan di Kelurahan Muara Dua Kota Prabumulih.

3. Kegiatan ini memperluas pemahaman dalam pengolahan data pada Usaha Penjualan Tanah Kavlingan di Kelurahan Muara Dua Kota Prabumulih.

\section{UCAPAN TERIMA KASIH}

Kami ingin mengucapkan terima kasih kepada LP2MK Universitas Indo Global Mandiri dan Pemilik Usaha Penjualan Tanah Kavlingan di Kelurahan Muara Dua, Kota Prabumulih.

\section{DAFTAR PUSTAKA}

A. Sanmorino, "Development of computer assisted instruction (cai) for compiler model: The simulation of stack on code generation," International Conference on Green and Ubiquitous Technology (GUT), Jakarta, pp. 121-123, July 2012.

H. Suhartanto, "Model Pemroses Bahasa Pemrograman Dengan tools berbasis Java, " Fakultas Ilmu Komputer Universitas Indonesia, 2012.

A. Sanmorino, S. Yazid, "DDoS Attack Detection Method and Mitigation Using Pattern of the Flow," IEEE International Conference of Information and Communication Technology, 2013. 